\title{
Statyba
}

\section{THE PROBLEMS OF RETROFITTING OF DWELLINGS}

\section{Stankevičius \& A. Burlingis}

To cite this article: V. Stankevičius \& A. Burlingis (1996) THE PROBLEMS OF RETROFITTING OF DWELLINGS, Statyba, 2:5, 71-79, DOI: 10.1080/13921525.1996.10531550

To link to this article: https://doi.org/10.1080/13921525.1996.10531550

册 Published online: 26 Jul 2012.

Submit your article to this journal $\pi$

III Article views: 63 


\title{
GYVENAMŲJŲ NAMŲ APŠLTINIMO PROBLEMOS
}

\author{
V. Stankevičius, A. Burlingis
}

Brangstant energijai pradejome taupyti silumą. Akivaizdu, jog pastatai yra prastai apšiltinti, todèl jiems šldyti suvartojame nemažai kuro. Atrodytų, viskas aišku - reikia papildomai apšiltinti pastatų atitvaras, ir tokiu būdu bus galima sutaupyti apie 50\% šlumos energijos per šildymo laikotarpi. Dažniausiai taip ir sako apšiltinančias medžiagas parduodančių firmų atstovai - jūs sutaupysite tam tikrą kiekị šilumos. Tačiau visada nutylima, kiek lěšų prireiks, norint papildomai apšiltinti pastatą. Su naujai statomais pastatais viskas aišku apšiltinančios medžiagos nedaug padidina bendrąsias statybos išlaidas.

Daug sudètingiau su senesniais pastatais. Papildomai ịdètos lẻšos jiems apšiltinti dažniausiai neatsiperka, kadangi didžiają lèšu dalị sudaro ne apšiltinančios medžiagos kaina, bet išorinè apdaila, ịvairios papildomos medžiagos bei islaidos, taip pat darbo kaina.

Šlumą taupyti apsimoka priklausomai nuo šiluminès energijos kainos, statybiniu medžiagu bei darbu kainos, nuo žemiausios palūkanų normos rinkoje, iš dalies - nuo gyventojų uždarbio dydžio. Jeigu kasmetiniai sutaupymai, papildomai apšiltinant pastatus, duotų pelną, didesnị už žemiausią rinkos pałūkanų normą, vertètų išleisti pinigus papildomam apšiltinimui, nei laikyti banke.

Anksčiau pastatytų gyvenamujų namų atitvarų apšiltinimo būklè pateikta 1 lenteleje, o Lietuvos gyvenamojo fondo duomenys - atitvary plotai F (ASI darbuotojos R.Levandauskienès), vidutiniai metiniai silumos nuostoliai sildymui Q bei kiti duomenys iki 19950101 - pateikti 2 lenteleje bei 1 paveiksle. Po apsiltinimo iki RSN-143-92 "Pastatų atitvarų šluminè technika" reikalavimų silumos nuostoliai sumažètų iki 1 paveiksle pateiktų reikšmių.

Remiantis Energetikos instituto darbuotojo habil.dr. V.Jankausko nuomone, artimiausią dešimtmetị Lietuvoje dèl léšu paklausos, ekonominiams skaičiavimams reikétų imti $10 \%$ gryną pelno/palūkanų normą Pasaulyje šiuo metu yra laukiamas $2.5 \%$ santykinis kuro brangimas. Galbūt, kainos ir nekis. Lietuvoje per artimiausius 10 metu, pasak habil.dr. V.Jankausko, nuo 1995 iki 2000 mety vidutinis santykinis silumos brangimas gali sudaryti apie $6 \%$ per metus, o nuo 2000 iki 2005 metu - apie 4.9\%/metai. Vadinasi, per ateinanti desimtmetį Lietuvoje vidutinis santykinis (grynas) šilumos brangimas gali sudaryti apie $5.4 \%$ kasmet. Remiantis šiomis prielaidomis bei tuo, kad paskola pastatams apšiltinti šiuo metu teikiama 10-čiai metu (dauguma gyventojų neturi "laisvų" pinigu), galima suskaičiuoti didžiausius dar atsiperkančius įdèjimus pastato atitvaroms papildomai apšiltinti iki RSN-143-92 reikalavimų. Skaičiavimai, pateikti 3, 4 lentelèse (bei 2, 3 ir 4 pav.), apytiksliai parodo léšų dydị, dar leidžiamą naudoti atitvaroms apšiltinti. Iš šių lentelių matome, jog daugelis atitvaras apšiltinančiu priemoniu neatsiperka. Reikia pridurti, kad gyventojams, ypač neturtingiems, patraukliausias yra paprastas $2-5$ metų atsipirkimo laikas. Leistinos lẻšos papildomai atitvaroms apšiltinti yra parodytos 2 paveiksle. 
1 lentelè. Lietuvos gyvenamųjų namų sienų, pastogès perdangų ir sutapdintų stogų šiltinančios savybès

\begin{tabular}{|c|c|c|c|c|}
\hline $\begin{array}{l}\text { Eil. } \\
\text { Nr. }\end{array}$ & Atitvaros pavadinimas & Storis, $\mathrm{cm}$ & $\begin{array}{c}\text { Tankis } \rho, \\
\mathrm{kg} / \mathrm{m}^{3}\end{array}$ & $\begin{array}{l}\text { Silumos varža } \\
\mathrm{R}, \mathrm{m}^{2} \mathrm{~K} / \mathrm{W}\end{array}$ \\
\hline 1 & Medinès $\quad \underline{\text { SIENOS }}$ & 15 & & $1.2-2.0$ \\
\hline 2 & $\begin{array}{l}\text { Mūrinès tinkuotos: } \\
\text {-pilnavidurių plytų } \\
\text {-skylètų plytų }\end{array}$ & $\begin{array}{l}51 \\
51\end{array}$ & & $\begin{array}{c}0.82 \\
1.0\end{array}$ \\
\hline 3 & Mūrinès su silikatinių plytų išorès apdaila & 51 & & 0.8 \\
\hline 4 & $\begin{array}{l}\text { Mūrinès su keraminių plytų išorès apdaila: } \\
\text {-pilnavidurių plytų } \\
\text {-skylètų plytų }\end{array}$ & $\begin{array}{l}51 \\
51\end{array}$ & & $\begin{array}{c}0.8 \\
0.92\end{array}$ \\
\hline 5 & Keramzitbetonio plokščiu & 35 & 1400 & 0.7 \\
\hline 6 & Keramzitbetonio monolito & 45 & 1400 & 0.85 \\
\hline 7 & Dujų betono plokšxių & 30 & $1000-800$ & $0.8-0.97$ \\
\hline 8 & Palengvintos iš dujų silikato blokelių & 32 & 600 & 1.08 \\
\hline 9 & $\begin{array}{l}\text { Mūrinès su oro tarpu: } \\
\text {-pilnavidurių plyty̨ } \\
\text {-skylėtų plytų }\end{array}$ & $\begin{array}{l}42 \\
42\end{array}$ & & $\begin{array}{l}0.78 \\
0.87\end{array}$ \\
\hline $\begin{array}{l}10 \\
11 \\
12 \\
\end{array}$ & $\begin{array}{l}\text { PASTOGESS PERDANGOS } \\
\text { Medinès su spaliu užpilu } \\
\text { Keraminių blokelių su šlako užpilu } \\
\text { G/b su šlako užpilu }\end{array}$ & $\begin{array}{c}15 \\
15-20 \\
15-20 \\
\end{array}$ & & $\begin{array}{c}1.45 \\
1.24 \\
1.0 \\
\end{array}$ \\
\hline 13 & $\frac{\text { SUTAPDINTI STOGAI }}{\text { G/b apšiltinti dujų betonu arba duju silikatu }}$ & 24 & 550 & 1.45 \\
\hline 14 & G/ḅ apsiltinti dujy betonu & $\begin{array}{l}12 \\
16 \\
\end{array}$ & $\begin{array}{l}400 \\
400 \\
\end{array}$ & $\begin{array}{l}1.27 \\
1.48\end{array}$ \\
\hline 15 & G/b apšiltinti kalibruotu duju betonu & $\begin{array}{l}24 \\
12 \\
16 \\
24\end{array}$ & $\begin{array}{l}400 \\
350 \\
350 \\
350 \\
\end{array}$ & $\begin{array}{l}2.07 \\
1.32 \\
1.61 \\
2.18\end{array}$ \\
\hline 16 & G/b apšiltinti maišperlixiu & $\begin{array}{c}8 \\
16\end{array}$ & $\begin{array}{l}100-150 \\
100-150\end{array}$ & $\begin{array}{l}1.92 \\
3.38\end{array}$ \\
\hline 17 & $\mathrm{G} / \mathrm{b}$ apšiltinti mineralinès vatos plokštèmis & $\begin{array}{c}6 \\
12 \\
\end{array}$ & $\begin{array}{l}175 \\
175\end{array}$ & $\begin{array}{c}1.39 \\
2.31 \mathrm{M}\end{array}$ \\
\hline
\end{tabular}

Vidutiniškai $1 \mathrm{~m}^{2}$ grindu; nuostoliai $\mathrm{kWh} /\left(\mathrm{m}_{\mathrm{gr}}{ }^{2 *}\right.$ metai)

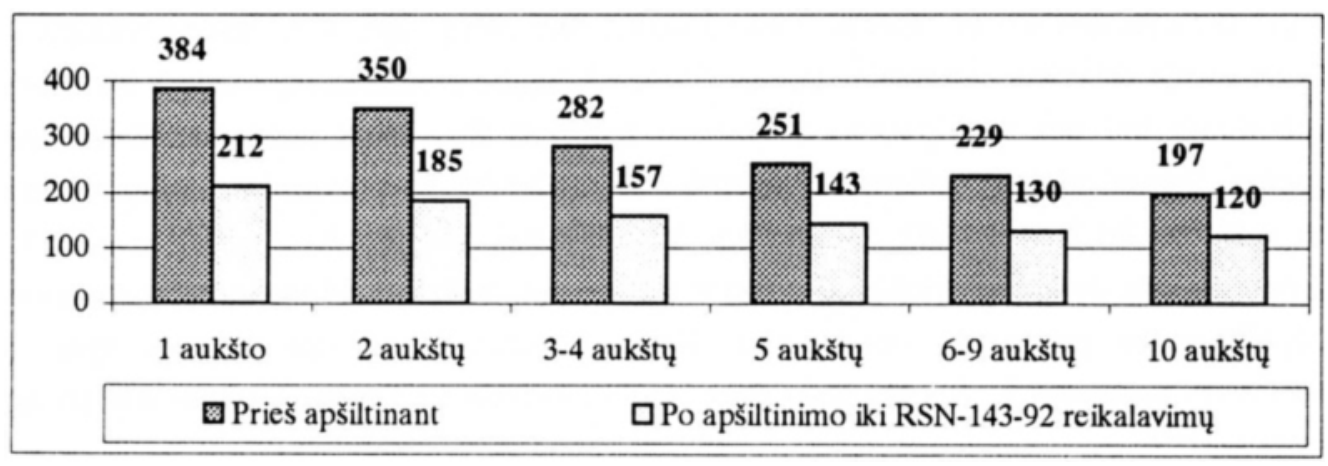

Pastaba: šilumos nuostoliai skaičiuoti esant $\mathrm{T}_{V}=20^{\circ} \mathrm{C} ; \mathrm{Z}=220$ parų; $\mathrm{T}_{\mathrm{ISS} \text {. vID }}=+0.5^{\circ} \mathrm{C}$.

1 pav. Pastatų vidutiniai metiniai lyginamieji šilumos nuostoliai prieš ir po apšiltinimo iki RSN-143-92 reikalavimy 


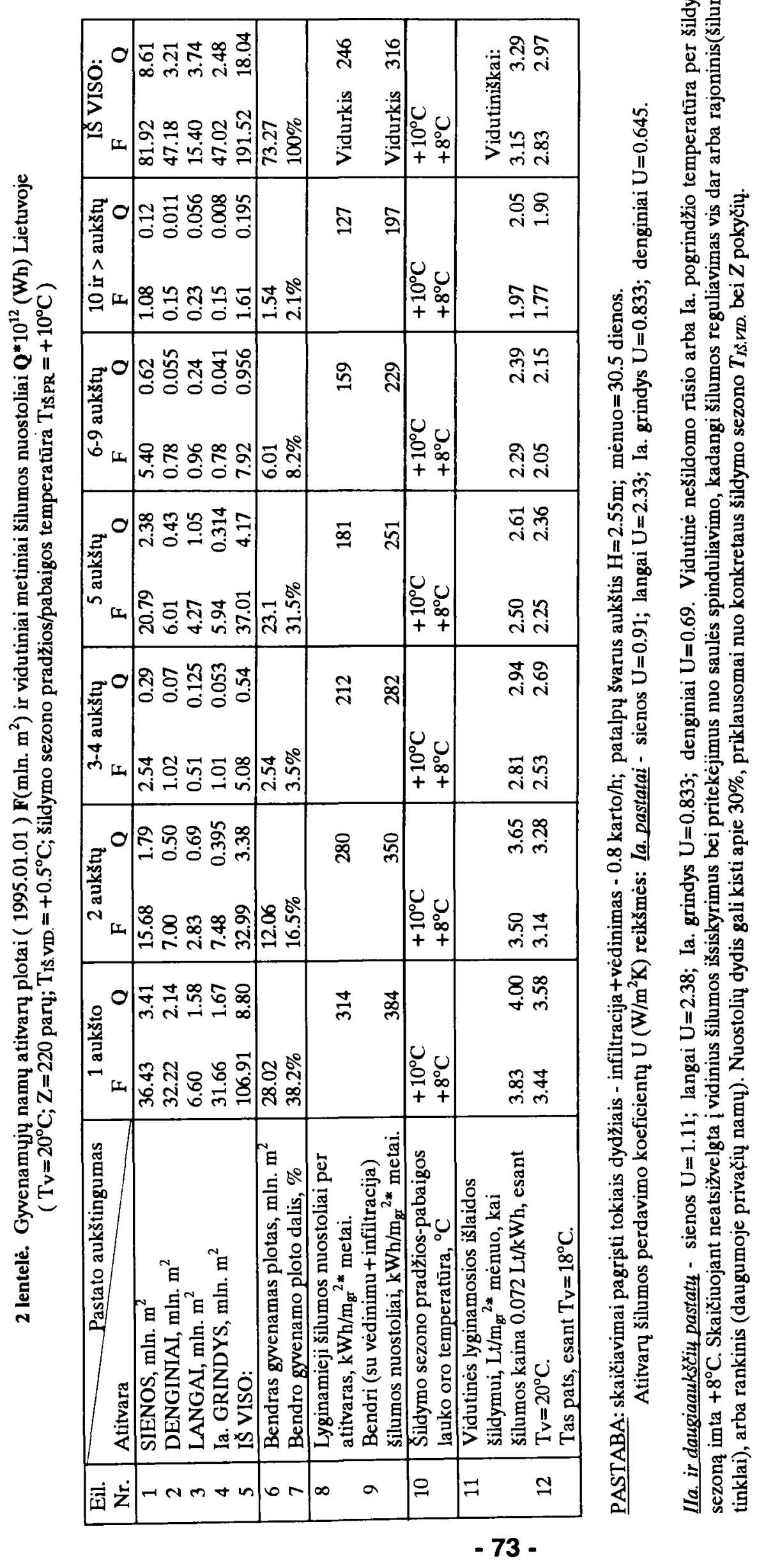




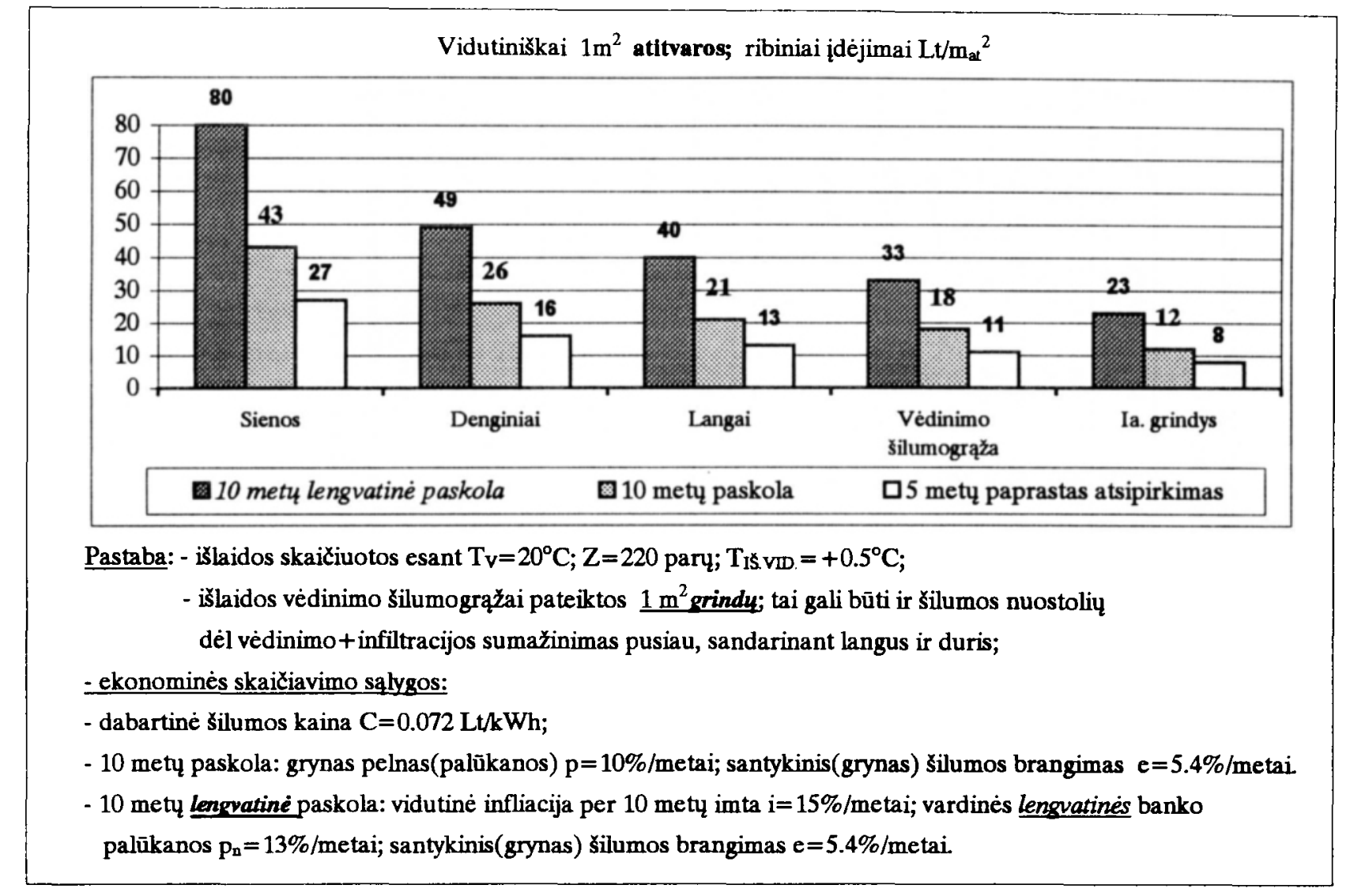

2 pav. Vidutiniai didžiausi dar atsiperkantys j̇dejjimai atitvaros apšiltinimui iki RSN-143-92 reikalavimų

Langal, sutaupymai $\mathrm{kWh} / \mathrm{m}^{2 *}$ metai

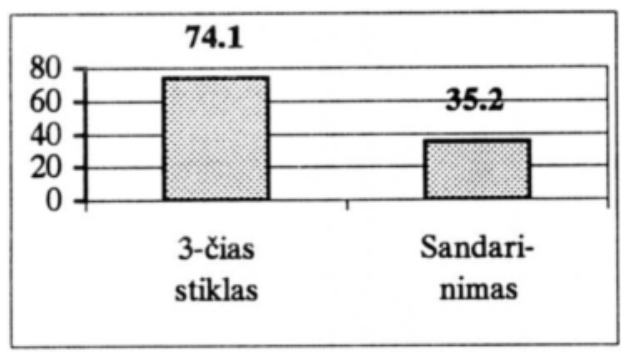

3 pav. Silumos sutaupymai, $\mathrm{kWh} / \mathrm{m}^{2 *}$ metai
Longai, sutaupymai $\mathrm{Lt} / \mathrm{m}^{2 *}$ metai

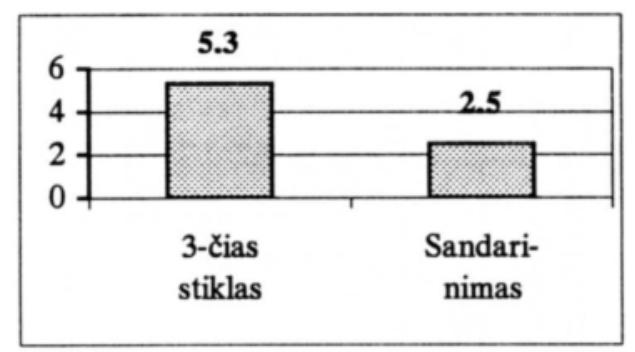

4 pav. Lèšų sutaupymai, Lt/m metai $^{2 *}$

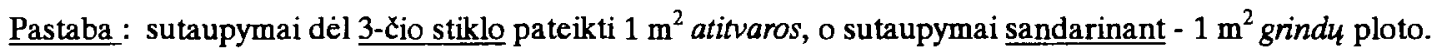

Skaičiavimų sąlygos: patalpų vidaus temperatūra $\mathrm{T}_{\mathrm{V}}=20^{\circ} \mathrm{C}$; šildymo trukmè $\mathrm{Z}=220$ paru;

vidut. lauko temperatūra šildymo laikotarpiu $\mathrm{T}_{\mathrm{IšvvD}}=+0.5^{\circ} \mathrm{C}$; šilumos kaina $\mathrm{C}=0.072 \mathrm{Lt} / \mathrm{kWh}$.

Galimi sutaupymai, sandariai jstacius 3-čiq stikla ( $1 \mathrm{mati.t.}^{2}$ atitvaros):

$\Delta \mathrm{T}=\mathrm{T}_{\mathrm{V}}-\mathrm{T}_{\mathrm{IS} . \mathrm{VID}}=19.5^{\circ} \mathrm{C} ;$ atitvaros plotas $\mathrm{F}=1 \mathrm{~m}^{2} ; \Delta \mathrm{U}=2.38-1.66=0.72$.

$\Delta \mathrm{Q}=\left(\Delta \mathrm{U}^{*} \Delta \mathrm{T}^{*} \mathrm{~F}^{*} \mathrm{Z}^{*} 24\right) / 1000\left[\mathrm{kWh} / \mathrm{m}_{\mathrm{atit} .}{ }^{2}\right.$ metai].

$\Delta \mathrm{Q}=\left(0.72 * 19.5^{*} 1^{*} 220^{*} 24\right) / 1000=74.13\left[\mathrm{kWh} / \mathrm{m}_{\text {atit. }}{ }^{2}\right.$ metai $]$.

$\mathrm{S}=74.13^{*} 0.072=5.30\left[\mathrm{Lt} / \mathrm{m}_{\text {atit. }}{ }^{2}\right.$ metai $]$.

Galimi sutaupymai užsandarinant langus ir duris :

$\Delta \mathrm{Q}=\left(\Delta \mathrm{n}^{*} 0.335^{*} \Delta \mathrm{T}^{*} \mathrm{H}^{*} \mathrm{Z}^{*} 24\right) / 1000\left[\mathrm{kWh} / \mathrm{m}_{\mathrm{gr.}}{ }^{2}\right.$ metai], čia $\Delta \mathrm{n}$ - skirtumas tarp senojo didesnio ir naujojo mažesnio patalpos oro pasikeitimų skaičiaus per valandą. 


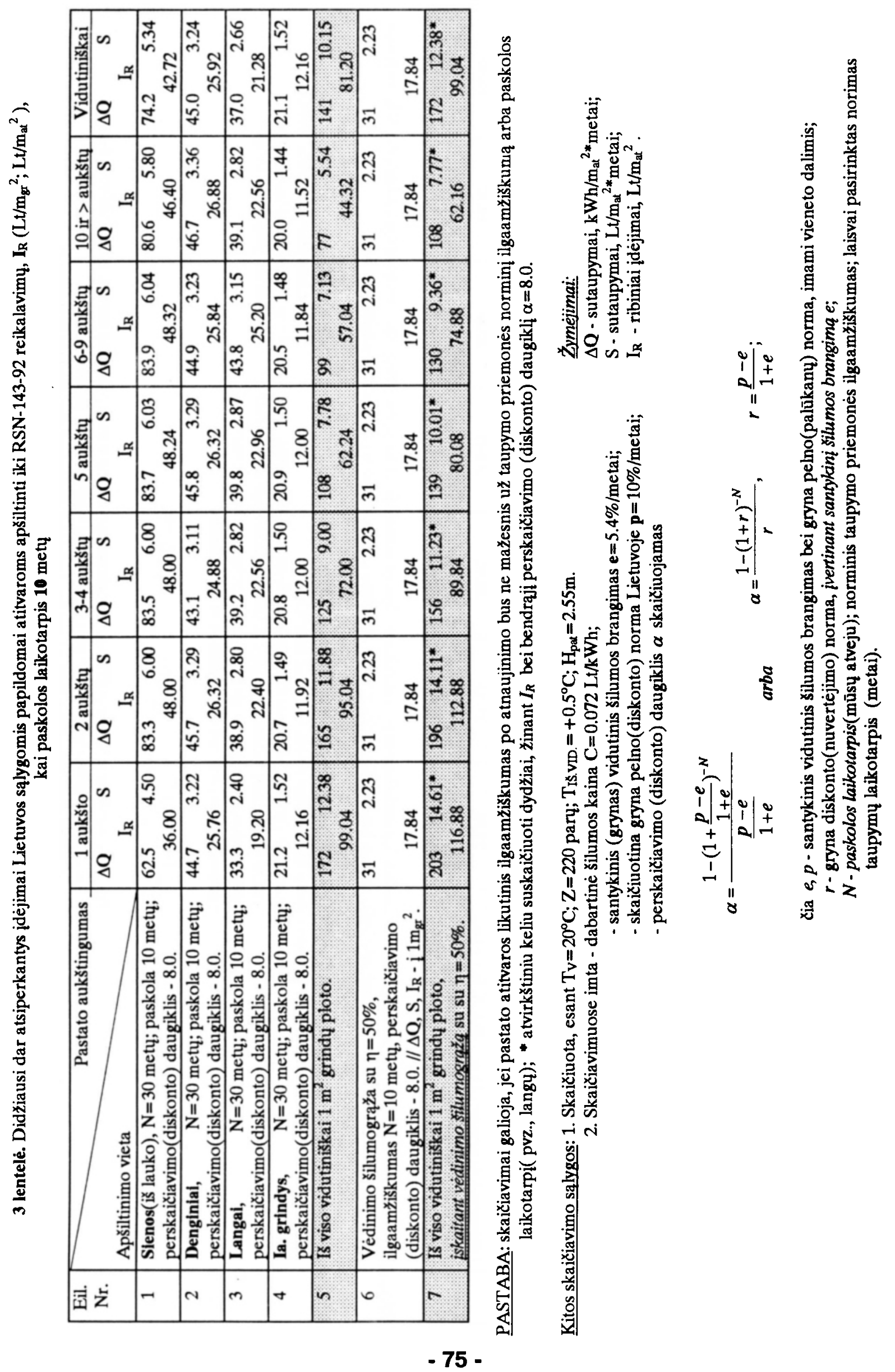




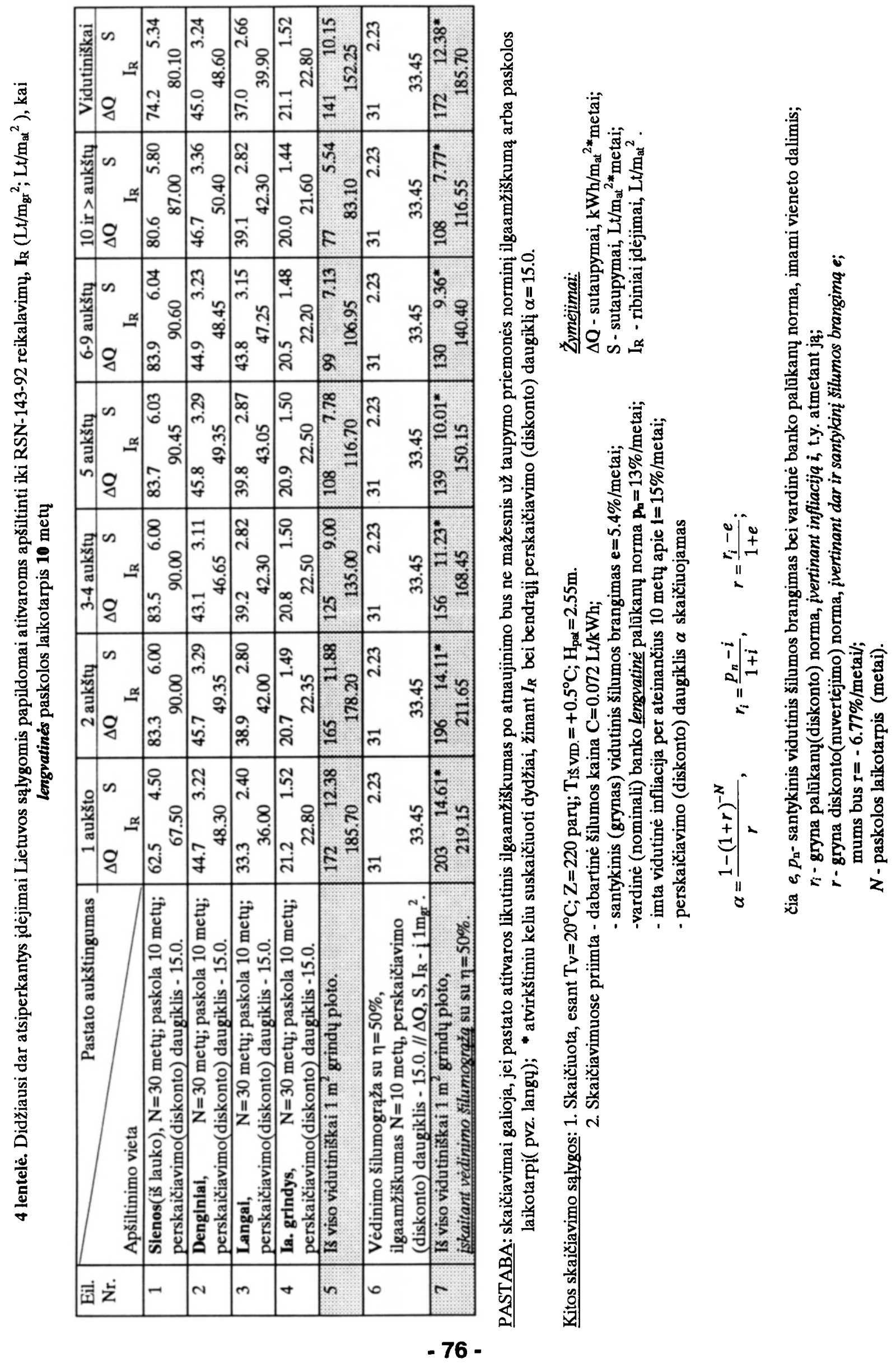


Jei laikysime, kad per šildymo laikotarpi pastaty vidutinis oro pasikeitimu skaičius $n_{s}=0.9 \mathrm{k} / \mathrm{h}$, o naujasis oro pasikeitimų skaičius užsandarinus langus ir duris $n_{n}=0.5 \mathrm{k} / \mathrm{h}$, tai oro pasikeitimų skirtumas $\Delta \mathrm{n}=0.4 \mathrm{k} / \mathrm{h}$; patalpu "švarus" aukštis $\mathrm{H}=2.55 \mathrm{~m}$.

$\Delta \mathrm{Q}=\left(0.4^{*} 0.335^{*} 19.5^{*} 2.55^{*} 220^{*} 24\right) / 1000=35.18\left[\mathrm{kWh} / \mathrm{m}_{\mathrm{gr} .}{ }^{2}\right.$ metai $]$,

$\mathrm{S}=35.18^{*} 0.072=2.53\left[\mathrm{Lt} / \mathrm{m}_{\mathrm{gr}}{ }^{2}\right.$ metai $]$.

Šiuo metu, atsižvelgiant ị šilumą taupančių priemonių atsipirkimą bei ịdedamų lèsų dydį, galima siūlyti šuos taupymo būdus tokia eilès tvarka:

1. Langu ir dury sandarinimas (sutaupymo galimybès nuo 9\% 1-aukščiuose iki $17 \%$ daugiaaukščiuose namuose; atsiperka per 1.5-3 metus; lèšu ịdéjimai nedideli);

2. Taupių dušo galvučių ịrengimas (kaina apie $50 \mathrm{Lt}$; sutaupo apie $10 \%$ karšto vandens, tačiau tai labai priklauso nuo gyventojų ipročių);

3. Vandens čiaupy tèkmés ribotuvı irengimas (sutaupoma panašiai, kaip ir taupiu dušo galvučiu istatymas);

4. Visų blogai apšiltintų vamzdynų papildomas apšiltinimas, ypač rūsiuose, šilumos punktuose （greitai atsiperkanti ir santykinai pigi priemonè);

5. Atspindinčių plèvelių ịrengimas už radiatorių /iki $45 \%$ sutaupymų per sieną/ (čia reikia pabrèztĭ jog tarp radiatoriaus ir sienos turi būti bent $20 \mathrm{~mm}$ oro tarpas; paskutinieji tyrimai sioje srityje[2]: gaminant atspindinčios plevelès pagrindq su keteromis, sukuriami konvekcija kylantys oro srautai, kurie neleidłia ušsistovèti orui už radiatoriaus ir dideti oro temperatūrai; tokia keterota atspindinti plèvelè padeda sutaupyti iki $15 \%$ patalpu šlumos /kol ji nauja ir neapdulkejjusi/; deja, daug kur irengti ketiniai radiatoriai

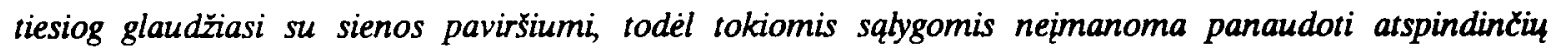
plevelius);

6. Trečio stiklo (arba skaidrios lavsaninès plèvelès/paketo; paketas- 5-8\%) istatymas i langą (stiklas atsiperka per 9-12 metu, sutaupo apie 4-6\% silumos; pagerina vidaus klimatą) /plačiau žiürèti 3 ir 4 pav./;

7. Priemonių derinys: atspindinčị šilumą žaliuzių istatymas $i$ lango tarpstiklę, neužtraukiant sunkiuju užuolaidy ant langu ir radiatorị sutemus; tai siūloma daryti, kai gyventojas nori pasikabinti žaliuzes ir dèl kitu (ne šilumos taupymo) priežasčị (bendruosius šilumos nuostolius galima sumažinti 4-5\% arba 26-27\% per langus);

8. Šildymo sistemos hidraulinis suderinimas /stovy krūvio suderinimas/ (iki 5\% sumažẻja šilumos nuostoliai);

9. Pastato క̌ilumos apskaitos ịrengimas (tai neišvengiamai būtina priemonè taupyti);

10. Šildymo sistemos automatinis reguliavimas:

- Silumos punkto/katilo darbas atsižvelgiant ị lauko temperatūrą (sutaupoma iki 5\% šilumos šildymui), - šildymo sumažinimas naktį $3-5^{\circ} \mathrm{C}$ (sutaupoma $5-8 \%$ šilumos šildymui),

- skirtingos patalpų temperatūros palaikymas dieną pagal aplinkybes,

- radiatorinių termoventilių su šilumos suvartojimo radiatoriniais davikliais įrengimas, t.y. kiekvienos patalpos temperatūros reguliavimas bei apskaita (sutaupoma 5\% šilumos šldymui);

11. Pastogès grindu apšiltinimas mažaaukščiuose pastatuose, ypač jei tai gali atlikti pats savininkas (galima sutaupyti apie $16 \%$ šilumos 1-aukščiuose ir $9 \%$ 2-aukščiuose namuose; paprastas atsipirkimo laikas 10 13 metų 1-aukščiams ir 20-24 metai 2-aukščiams namams);

12. Aklinų galinių sienų apšiltinimas iš vidaus, jei tai gali atlikti pats savininkas (visas daugiaaukštis namas gali sutaupyti apie $4 \%$ šilumos, tačiau atskiras butas gali sutaupyti nuo $12 \%$ viršutiniame aukšte iki $16 \%$ viduriniame); 
13. Rūsio lubų arba rūsio sienų apšiltinimas mažaaukščiuose pastatuose, jei tai gali atlikti pats savininkas (galima sutaupyti $6 \%$ šlumos 1-aukšciuose, $4 \%$ 2-aukšciuose, apie $2.5 \% 5$-aukščiuose ir $1.3 \% 10$ aukščiuose namuose).

14. Lodžijų ir balkonų istiklinimas, ypaz jei jos iš P, PV, PR, V pusès (taupant šilumą atsiranda dar ir papildoma erdvé, pagerèja greta esančios patalpos vidaus klimatas žiemą, tačiau ši erdvé turi būti vèdinama);

Visi anksčiau minimi sutaupytos šilumos \% nesumuojami. Jie gaunami, ịvertinant prieš tai panaudotus taupymo būdus.

Iš tikruju tik 8-10 šilumos taupymo būdai visas kitas taupymo galimybes paverčia tikrove, tačiau visada tikslinga pirmiau igyvendinti pačias pigiausias ir veiksmingiausias priemones, ypa $\mathfrak{x}$ jei jos pagerina vidaus klimatą - žiemą pakelia patalpų temperatūrą. Mažai kainuojancios, tačiau taip pat labai svarbios yra tokios priemonès:

- einamojo remonto bei priežiūros praktiniц taisykliu sudarymas ir ju laikymasis silumos punktuose, katilinèse, šildymo, karšto vandens, šalto vandens sistemose,

- energostabos ivedimas (ypač esant automatiniam šildymo sistemos reguliavimui), t.y. kiekvieną savaitę stebèti ir užrašyti žurnale duomenis apie suvartotą energiją šildymui ir karštam vandeniui gyvenamajame name, lyginti su teoriniu arba praktiniu šilumos suvartojimu, priklausančiu nuo vidutinès lauko temperatūros per savaitę; tai leidžia labai greitai pastebèti sutrikimus ir nedelsiant juos ištaisyti.

Vèdinimo šilumogrążos ịrengimas kol kas neatsiperka, be to, tai sunku ịrengti jau pastatytuose ir tam nepritaikytuose betoniniuose mūriniuose pastatuose (galima sutaupyti iki 8\% šlumos 1 -aukščiuose, $13 \%$ 5-aukšciuose, 16\% 10-aukščiuose namuose). Apšiltinti sienas iš lauko taip pat kol kas neapsimoka, nors tokiu būdu galima sutaupyti apie $21 \%$ šilumos 1 -aukščiuose, $34 \% \quad 5$-aukščiuose, $36 \%$ 10-aukščiuose namuose. Norint, kad Siltinimo priemones atsipirktu, reikn atskinti kapitaliniam remontui ir šlltinimui skirtu lés̆u finansavimo saltinius, kadangi taupo tik siltinimas, o jo dèka norima atpirkti ir kapitalinio remonto išlaidas. Teikiant paskolas, teisingiausia būtų lengvatines paskolas skirti pastatu kapitaliniam remontui, o paskolas be lengvatu šilumą taupančioms priemonėms pastatuose ịrengti. Pirmiausiai apšiltinti reiktų tuos gyvenamuosius namus, kuriems reikalingas neatidèliotinas kapitalinis remontas.

Remiantis norvegu konsultacinès firmos ENSI (Energy Saving International AS) praktinių stebejjimu duomenimis, galima sutaupyti tokiais būdais:

- energostabos ivedimas - sutaupoma $3 \%$ bendro energijos suvartojamo kiekio (šldymui + karštam vandeniui);

- einamojo remonto bei priežiūros taisykliy sudarymas ir laikymasis - sutaupoma $3 \%$ bendro energijos suvartojamo kiekio, atmetus prieš tai panaudotos taupymo priemonès sutaupymus;

- sildymo sistemos hidraulinis suderinimas padeda sutaupyti iki 5\% suvartotos šilumos šildymui;

- šildymo sistemos automatinio reguliavimo įvedimas sutaupo taip pat iki 5\% suvartotos silumos patalpy šildymui, atmetant anksčiau pritaikytos priemonès sutaupymus;

- radiatorinių termoventilių įrengimas su vietiniais šilumos vartojimo davikliais - iki 5\% suvartotos šilumos šildymui, atmetant anksčiau pritaikytu taupančių priemonių sutaupymus;

- karšto vandens sistemos automatinis temperatūros reguliavimas - sutaupoma apie $10 \%$ šilumos karštam vandeniui paruošti.

Vengrijoje sildymo sistemos automatinio reguliavimo ir šilumos apskaitos ịvedimas davè dar geresnius rezultatus[1]. Buvo paimti du vienodi šalia stovintys 10-ties aukštu gyvenamieji paneliniai namai - geros būklès, pastatyti prieš 12 metų. Pertvarkymams buvo panaudotos tokios priemonès: radiatoriniai termoventiliai, radiatoriniai šilumos matavimo davikliai, vandens skaitikliai butuose, viso namo šilumos skaitiklis, viso namo karšto vandens debito ir šilumos skaitikliai, 2-jų zonų (fasadams) šildymo sistemos temperatūros skaitmeninis 
reguliatorius pagal lauko oro temperatūrą (šilumos punkte), patalpų temperatūros skirtingas nustatymas per parą bei savaitę, slègiu skirtumo reguliatorius sildymo sistemoje (కilumos punkte), automatinis su elektros pavara trieigis vandens sumaišymo ciaupas šildymo sistemoje (šilumos punkte), siurblys su dažnuminiu greičio keitikliu (šlumos punkte).

Gauti tokie bandymo rezultatai (lyginant su palyginamuoju nepertvarkytu namu) :

- bendras šiluminès energijos suvartojimas mažesnis $38 \%$;

- Silumos suvartojimas šildymui mažesnis $35 \%$;

- šilumos suvartojimas karštam vandeniui paruošti mažesnis $44 \%$;

- karšto vandens suvartota $60 \%$ mažiau.

Taip pat pastebéti dideli šilumos suvartojimo skirtumai atskiruose butuose, priklausantys nuo gyventoju ipročių.

Ir Lietuvoje didžiausias dèmesys turètų būti skirtas šildymo sistemoms pertvarkyti, t.y. automatizuoti bei kruopščiai vartojimo apskaitai ịvesti tiek visam pastate, tiek butuose (dalis taupymo priemonių, kurios neapsimoka visam namui, gali apsimokèti atskiram butui), nes tikètis greito geranoriško gyventojų iproču pasikeitimo taupant ir neturint iš to naudos, būtų beveik beviltiska.

\section{Literatūira}

1. Gyorgy Boganyi and Preben Caroe. Energy Saving in District Heating. Phare project, Eger, Hungary // Energy Efficient Building. 1994, p. 171 -174. Published by James and James Limited. London, UK, 344 p.

2. Nick Christy. Reducing Heat Loss Behind Radiators. The novitherm insulation panel // Sustainable and Energy Efficient Building. 1995, p. 168 -170. Published by James and James Limited. London, UK, 432 p.

Iteikta 19960120

\section{THE PROBLEMS OF RETROFITTING OF DWELLINGS}

\section{Stankevičius, A. Burlingis}

\section{S u m m a r y}

With the rise of energy prices, the need for saving energy have increased. The existing buildings are poorly insulated, so it seems enough to insulate building envelope additionally and in such a way to save about $50 \%$ of annual energy consumption for heating. But there are some problems here. With new constructions everything is clear - the insulating materials do not enlarge the overall cost of building too much. But the situation becomes much more complicated with the existing poorly insulated buildings. The profitability of energy savings in dwelling buildings depends on the relationship between the prices of energy, building materials and workmanship, the market lowest interest rate and partly on average earnings of the inhabitants. The paper submits the data of Lithuania's dwelling stock - thermal conditions of enclosures, dwelling areas, annual average heat losses before and after insulation of enclosures according to the requirements of the building code RSN-143-92 "Thermal Technique of Buildings". We have also calculated the limit investments into additional insulation of enclosures, depending on duration of a bank loan, a bank interest rate, present price of heating and expected probable relative energy price increase in Lithuania. The paying back energy conservation measures and priorities of realization of those measures are suggested under Lithuanian conditions too. 